\title{
MAKNA RUANG SEBAGAI ASPEK PELESTARIAN SITUS SUMBERAWAN
}

\author{
Syamsun Ramli ${ }^{1}$, Respati Wikantiyoso ${ }^{2}$ \\ ${ }^{1}$ Mahasiswa Program Studi Magister Arsitektur Lingkungan Binaan, Universitas Brawijaya, Malang \\ ${ }^{2}$ Guru Besar arsitektur perkotaan, Universitas Merdeka Malang, Malang \\ 1apuirek@gmail.com
}

\begin{tabular}{|c|c|}
\hline & ABSTRAK \\
\hline $\begin{array}{l}\text { Kata Kunci: } \\
\text { Mitos, Stupa, } \\
\text { Telaga Mata Air, } \\
\text { Pelestarian }\end{array}$ & $\begin{array}{l}\text { Situs Sumberawan merupakan salah satu tempat wisata di kabupaten Malang. Situs ini } \\
\text { terletak di Desa Toyomerto, Kecamatan Singosari. Stupa Sumberawan berada di kaki } \\
\text { gunung Arjuno. Stupa Sumberawan dibangun pada akhir era Majapahit, yaitu sekitar } \\
\text { abad ke-14 sampai 15. Di area stupa terdapat beberapa mata air. Mata air ini membentuk } \\
\text { telaga mata air. Stupa Sumberawan dibangun untuk mentransformasi mata air menjadi } \\
\text { tirta amerta. Tirta amerta adalah air suci sebagai saripati kehidupan. Masyarakat masih } \\
\text { mempercayai mitos dan larangan di telaga mata air ini. Situs Sumberawan sangat menarik } \\
\text { untuk diteliti dengan keberadaan telaga mata airnya. Stupa dan telaga mata air ini menjadi } \\
\text { ruang berbagai aktivitas. Warga sekitar memanfaatkannya untuk kebutuhan air bersih, } \\
\text { mencuci, memancing, dan mengairi sawah. Umat Budha melakukan ritual pradaksina } \\
\text { di Stupa Sumberawan. Penganut kejawen melaksanakan ritual mandi suci pada malam } \\
\text { jumat legi di telaga mata air. Wisatawan berkunjung dengan tujuan rekreasi. Peneliti } \\
\text { ingin mengetahui makna ruang Situs Sumberawan bagi masing-masing pengguna. } \\
\text { Penelitian menggunakan metode studi literatur. Hasil penelitian menunjukan perbedaan } \\
\text { pemaknaan dan penggunaan ruang di Situs Sumberawan. Perbedaan makna ruang ini } \\
\text { dapat menjadi landasan dalam upaya pelestarian Situs Sumberawan. }\end{array}$ \\
\hline
\end{tabular}

\section{ABSTRACT}

Keywords: Myth, Stupa, Lake springs, Preservation
Sumberawan temple is one of the tourist attractions in Malang Regency. This temple is located in Toyomarto Village, Singosari District. Sumberawan Stupa is located on the slopes of Mount Arjuno. Sumberawan Stupa was built at the end of Majapahit era, which is around the 14th century until 15th. In the stupa area, there are several springs. These springs form the lake of spring water. Sumberawan Stupa was built to transform the spring into tirta amerta. Tirta amerta is the holy water as the essence of life. People still believe in myths and restrictions in the lake of this spring. Stupa Sumberawan is very interesting to be studied by the existence of lake of spring water. Stupa and lake springs is a space of various activities. Residents use it for clean water, washing, fishing, and irrigating rice fields. Buddhists perform a ritual pradaksina in the Sumberawan Stupa. Kejawen perform the holy bathing ritual on Friday night legi at lake springs. Tourists visiting with recreation purposes. Researchers want to know the meaning of Resource Site space for each user. Research using literature study method. The results showed the difference of meaning and use of space in Sumberawan Site. The difference in the meaning of this space can be the foundation in the effort to preserve Sumberawan Site.

@ 2017 The Authors. Published by GKAK UNMER Malang

*Corresponding Author: apuirek@gmail.com 


\section{Pendahuluan}

Situs Sumberawan (Stupa Sumberawan dan telaga mata air) berada di desa Toyomarto, kecamatan Singosari, kabupaten Malang. Penamaan toyomarto berhubungan dengan kepercayaan bahwa air Sumberawan adalah tirta amerta. Toyo berarti air dan marto dari kata amerta berarti tidak mati/ hidup (Titisari, 2016). Sumberawan berasal dari bahasa Sanksekerta bariawan/ bhariwahana yang berarti penunggang merak yaitu Sang Budha (Sunyoto, 2000). Namun ada juga yang berpendapat nama Sumberawan berasal dari kata sumber dan rawan (Wurianto, 2009). Di sekitar stupa terdapat banyak sumber mata air yang membentuk telaga (rawan). Sehingga warga sekitar menyebutnya Candi Rawan (Suwardono, n.d.). Stupa Sumberawan berada di sisi selatan kaki Gunung Arjuno (Wurianto, 2009). Lingkungan alam sekitar stupa Sumberawan masih asri dikelilingi oleh hutan pinus dan bambu. Letak Stupa Sumberawan sekitar 650 meter di atas permukaan laut. Udara di situs Sumberawan terasa sejuk. Lokasi Stupa Sumberawan menunjukan bahwa pada umumnya bangunan pemujaan roh nenek moyang berada di tempat yang tinggi (Marsudi, 2015).

Masyarakat jawa mempercayai mitos bahwa gunung Penanggungan, Lawu, Wilis, Kawi, Kemukus, Kelud, Arjuno, dan Semeru merupakan gunung suci (Titisari, Antariksa, Dwi, \& Surjono, 2017). Karena berasal dari gunung yang dianggap suci, maka mata air dan dan kalen (sungai dari aliran airnya) juga dianggap suci (Cahyono, 2017). Begitupun sumber air yang terdapat di Situs Sumberawan yang berada di lereng Gunung Arjuno. Stupa Sumberawan dibangun pada akhir era Majapahit, yaitu sekitar abad ke-14 sampai 15 (Titisari, 2016). Stupa Sumberawan dibangun untuk mentransformasi mata air menjadi tirta amerta. Transformasi ini tidak merubah wujud air, namun merubah sifat dan khasiat air menjadi tirta amerta (Nuryadi, 2017). Tirta amerta adalah air suci sebagai minuman para dewa. Apabila orang biasa meminum tirta amerta dipercaya akan terhindar dari bala atau kematian (Wurianto, 2009).

Masyarakat setempat menggunakan kalen (sungai aliran air dari telaga mata air) untuk mencuci, mandi maupun mencari ikan. Kalen bagi anak-anak setempat adalah tempat bermain sehari-hari. Situs Sumberawan juga merupakan destinasi wisata di Desa Toyomarto. Wisatawan Situs Sumberawan terbagi menjadi dua kelompok berdasarkan tujuan mendatangi Situs Sumberawan. Kelompok pertama adalah pengunjung dengan tujuan melakukan ritual keagamaan. Kelompok kedua pengunjung dengan tujuan non-ritual keagamaan. Pengunjung ritual keagamaan dibagi menjadi 3 kelompok: (1) kelompok yang menjadikan stupa sebagai tempat ibadah, yaitu umat Budha; (2) kelompok yang percaya mitos khasiat telaga mata air dengan latar belakang dari berbagai agama; (3) kelompok yang memiliki hubungan spiritual dengan Situs Sumberawan, yaitu mereka yang menyakini tempat tersebut adalah tempat Raden Wijaya mengasingkan diri dan bersemedi (Titisari, 2016).

Di dalam Piagam Pelestarian Pusaka Indonesia memaparkan bahwa Pusaka Indonesia adalah pusaka alam, pusaka budaya, dan pusaka saujana. Juga dikemukakan telah terjadi pendangkalan, pemiskinan budaya, dan melemahnya daya cipta, prakarsa, dan rasa percaya diri bangsa (JPPI \& ICOMOS, 2003).

\section{Permasalahan}

Situs Sumberawan didatangi oleh berbagai pengunjung dengan tujuan yang berbeda-beda. Perbedaan tujuan dan aktivitas memperlihatkan perbedaan dalam memaaknai Situs Sumberawan. 


\section{Makna Ruang Sebagai Aspek Pelestarian Situs Sumberawan}

Syamsun Ramli \& Respati Wikantiyoso

Menarik untuk menelaah penggunaan ruang dan bagaimana pengunjung memaknai ruang tersebut. Penulis memiliki hipotesa bahwa makna ruang terhadap Situs Sumberawan berkaitan erat dengan upaya pelestarian kawasan tersebut.

\section{Tujuan Penelitian}

Penelitian ini bertujuan untuk mengetahui penggunaan ruang dan makna ruang masyarakat sekitar maupun pengunjung di Situs Sumberawan. Sehingga dapat diketahui upaya dalam pelestarian Situs Sumberawan.

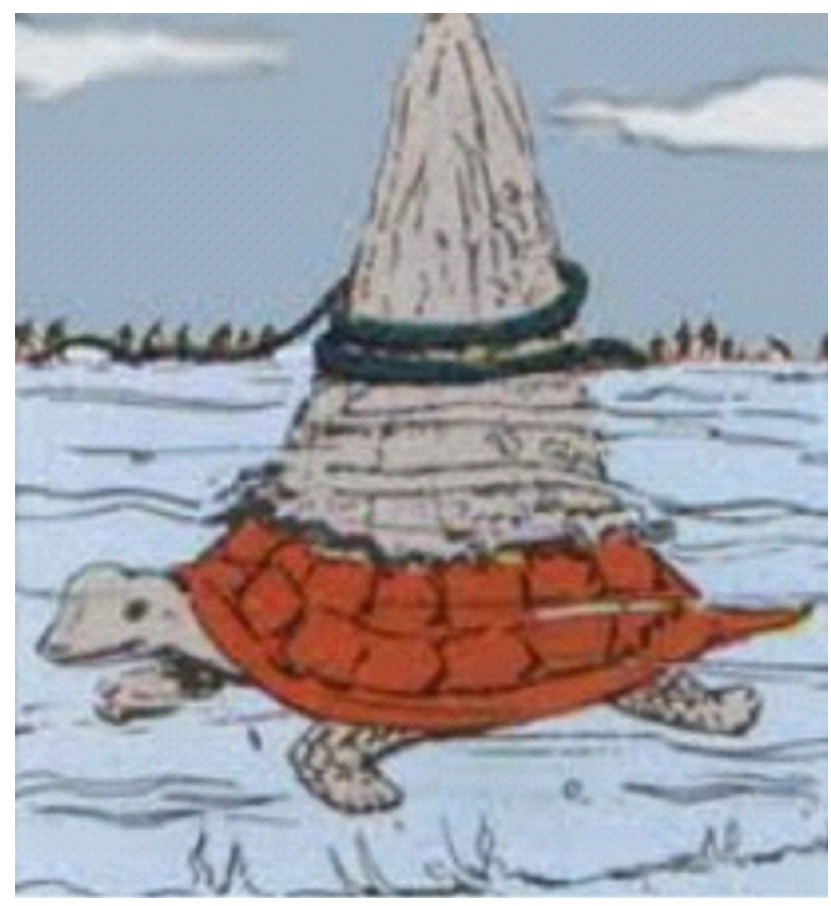

Gambar 1. Ilustrasi Pengambilan Tirta Amerta

(Sumber: http://www.pasramanganesha.sch.id, 2012)

\section{Metode Penelitian}

Penelitian ini menggunakan metode studi literatur. Peneliti mengolah berbagai literatur yang berkaitan dengan penggunaan ruang dan pemaknaan ruang baik oleh msyarakat sekitar maupun pengunjung situs Sumberawan. Data diperoleh melalui jurnal penelitian, surat kabar online, maupun situs internet yang berkaitan dengan kawasan stupa Sumberawan. Peneliti menelaah: (1) tirta amerta; (2) Stupa Sumberawan; (3) pengguna Situs Sumberawan dan ruang yang digunakannya; (4) bagaimana makna Situs Sumberawan bagi masing-masing pengguna. Berbagai penggunaan ruang dan makna ruang ini dijadikan landasan dalam upaya pelestarian Situs Sumberawan. 


\section{Tirta Amerta Sebagai Air Suci}

Di dalam Kitab Adiparwa, Akupa adalah nama seekor kurma (kura-kura) sebagai penjelmaan kedua Dewa Wisnu. Akupa mengapung di lautan susu (Kserasagara atau Kserarnawa) dimana terdapat tirta amerta di dasarnya (Ganesha, 2017). Amerta adalah air suci minuman para dewa. Apabila manusia meminum amerta maka akan terhindar dari bala bencana dan kematian (Wurianto, 2009). Untuk mendapatkan tirta amerta para Dewa dan Asura harus mengaduk Kserasagara dengan Gunung Mandara Giri. Gunung Mandiri Giri diikat menggunakan Naga Basuki oleh para Dewa dan Asura. Akupa dengan menggunakan tempurungnya menopang Gunung Mandiri Giri tersebut. Dewa Indra memegang puncak gunung Gunung Mandiri Giri, kemudian para Dewa dan Asura memutar gunung tersebut. Akhirnya tirta amerta didapatkan dan kemudian Dewa Wisnu menguasainya (Ganesha, 2017).

\section{Stupa Sumberawan}

Dikisahkan dalam kitab Tantu Pagelaran bahwa Bhatara Guru berkeinginan agar manusia dapat tinggal di jawa (Yawadwipa). Namun saat itu Yawadwipa masih sering berguncang sehingga belum bisa dihuni manusia. Karena itu Bathara Guru memerintahkan agar Gunung Mahameru dipindahkan ke Jawadwipa dari Jambudwipa di India. Pemindahan ini dilakukan oleh para dewa, bidadari, perempuan dari surga, resi, manusia setengah dewa (Setyani, 2011). Awalnya Gunung Mahameru diletakan di ujung barat Yawadwipa, namun bagian timur Yawadwipa menjadi mencuat. Kemudian para dewa memindahkan setengah puncak Mahameru ke sebelah timur, dan menjadi Gunung Pawitra (Gunung Penanggungan) yang berada di Kabupaten Mojokerto sekarang (Setyani, 2011). Puncak Gunung Mahameru menyerpih menjadi Gunung Kawi, Lawu, Kemukus, Wilis, Kelud, Arjuno, dan Semeru pada saat dipindahkan (Titisari, 2017). Perpindahan ini diikuti oleh para Dewa yang tinggal di puncaknya (Setyani, 2011). Orang jawa mempercayai gunung sebagai tempat bersemayam para dewa dan roh nenek moyang sehingga dianggap suci. Kepercayaan ini sudah ada sebelum agama Hindu-Budha masuk pulau jawa (Marsudi, 2015). Sehingga di lereng kaki Gunung Arjuno ditemukan banyak petilasan yaitu punden berundak, menhur, arca, lesung, dan patirtan (Marsudi, 2015).

Tradisi keagamaan asli orang jawa muncul kembali pada saat pengaruh Hindu-Budha melemah. Setelah lama terdesak oleh agama Hindu-Budha selama berabad-abad munculah kembali tradisi pemujaan terhadap gunung dan roh nenek moyang. Kebangkitan kepercayaan Jawa lama ini menyebabkan munculnya tempat-tempat pemujaan arwah leluhur di lereng-lereng gunung. Hal ini merupakan kebangkitan tradisi megalitik dalam format yang baru, yaitu neo-megalitik (Marsudi, 2015). Peninggalan neo-megalitik yang ada di lereng Gunung Arjuno antara lain: Punden Batik Madrim, Goa Antaboga, Punden Rahtawu, Artefak Puthuk Lesung, Dewi Kunthi, Reco Semar, Punden Makutha Rama, Punden Wesi, dan Candi Sepilar. Peninggalan-peninggalan ini diperkirakan berdiri sekitar abad XIV-XV (Djafar, 2012). Stupa Sumberawan adalah salah satu petilasan di lereng Gunung Arjuno.

Sumberawan diyakini sebagai tempat Raden Wijaya mengasingkan diri dan bersemedi sebelum menemukan dan mendirikan Majapahit (Titisari, 2016). Sebelum stupa Sumberawan didirikan, Raja Hayam Wuruk (Raja Majapahit) melakukan perjalanan keliling. Pada saat itu daerah Singosari merupakan tempat bermukim para pendeta Shiwa-Budha. Raja memberikan tanah Sumberawan kepada para pendeta Shiwa-Bhuda. Kemudian didirikan candi Budha berbentuk stupa (Titisari, Antariksa, Dwi, \& Surjono, 2017). Puncak Stupa merupakan simbol nirvana (moksa, manunggaling kawula lan Gusti) (Titisari, 2017). 


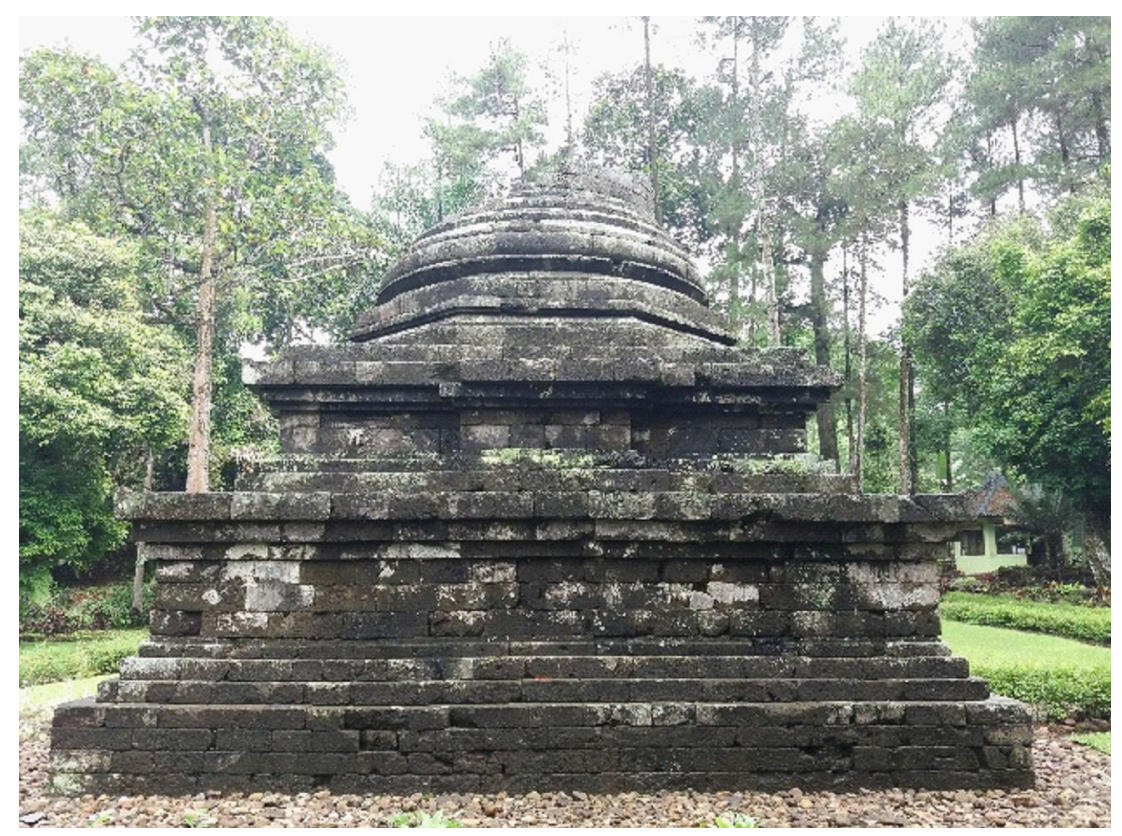

Gambar 2. Stupa Sumberawan (Sumber: Syamsun, 2017)

Stupa Sumberawan berukuran panjang 6,25 m, lebar 6,25 m, dan tinggi 5,23 m (Titisari, 2017). Tingkatan Stupa Sumberawan yaitu batur, kaki segi empat, kaki segi delapan, auda, harmika, charta. Stupa senbenarnya dalah kaki segi 8 dengan bantalan seroja/teratai sebagai lambang kahyangan dan tubuh berbentuk genta. Charta/ payung tidak dipasang kembali pada saat pemugaran, karena tidak ditemui sisa-sisa peninggalannya (Suwardono, n.d.). Pada umumnya stupa sebagai tempat menyimpan sisa kremasi dari Budha, orang suci, ataupaun seorang raja (Sugata, 2016). Namun di Stupa Sumberawan ataupun sekitarnya tidak ditemukan relik, abu jenazah, arca seperti umumnya candi-candi Budha. Stupa Sumberawan baru ditemukan pada tahun 1904, walaupun telaga mata air sudah lama dijadikan sarana hidup oleh masyarakat setempat (Wurianto, 2009). Pada tahun 1928 dan 1935 Pemerintah Belanda merenovasi Stupa Sumberawan (Wurianto, 2009).

Pengawasan Situs Sumberawan berada di bawah kewenangan Balai Pelestarian Peninggalan Kepurbakalaan Trowulan Mojokerto (Wurianto, 2009). Situs ini dapat dijangkau dengan mudah, karena sarana jalan sudah tersedia dengan baik. Jarak dari Kecamatan Singosari kurang-lebih 6 kilometer ke sebalah barat (Suwardono, n.d.).

\section{Stupa Sumberawan Sebagai Gunung Mandara}

Stupa Sumberawan didirikan dengan tujuan untuk untuk mentransformasi mata air menjadi tirta amerta. Sehingga Stupa Sumberawan berfungsi sebagai sebagai Gunung Mandara dan telaga mata air di sekelilingnya sebagai Kserasagara (Wurianto, 2009). Transformasi ini tidak merubah wujud air, namun merubah khasiat dan sifat air menjadi tirta amerta. Amerta berasal dari bahasa sanksekerta amrta. Amerta terbentuk dari kata $a$ yang berarti tidak, dan mrta yang berarti mati, sehingga amerta mempunyai arti 
tidak mati (Nuryadi, 2017). Masyarakat mempercayai mitos khasiat telaga mata air Sumberawan. Buktibukti yang memperkuat mitos ini adalah terkabulnya doa yang dipanjatkan oleh sebagian orang yang berdoa, mandi, dan meminum air Sumberawan. Doa-doa yang dipanjatkan berkenaan dengan kesehatan, kekayaan, dan jabatan (Titisari, 2017).

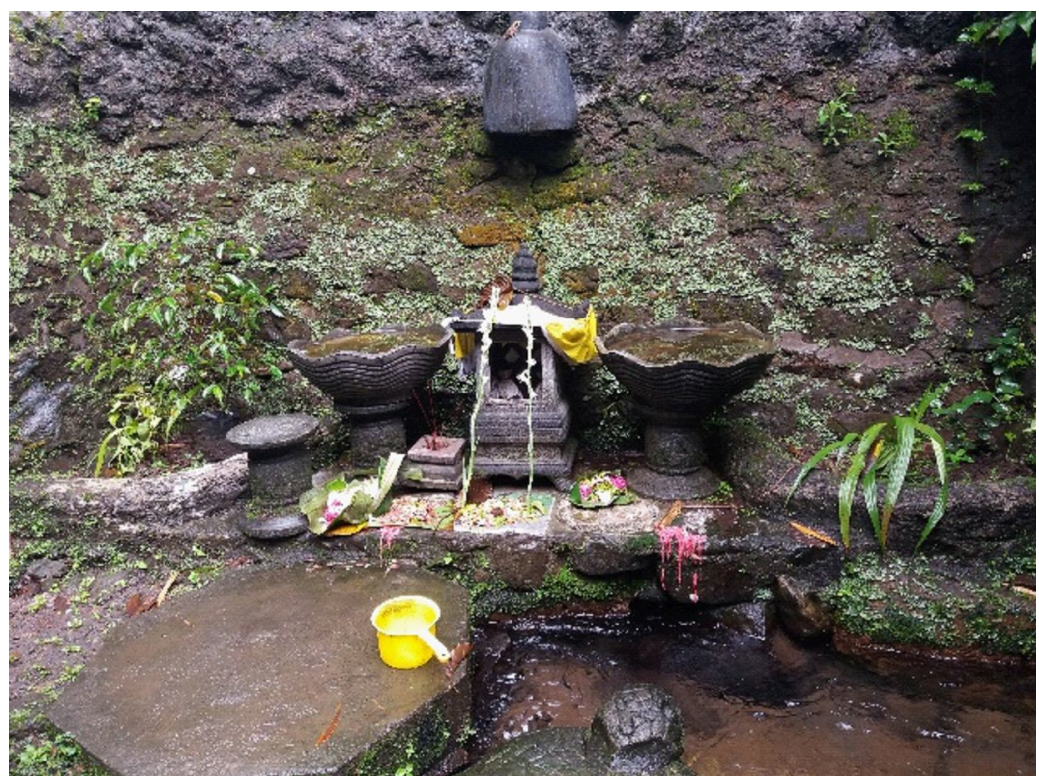

Gambar 3. Mata Air Situs Sumberawan

(Sumber: Syamsun, 2017)

Dalam kitab Negara Kertagama pupuh XXXV, Sumberawan disebut sebagai Kasurangganan (Titisari, 2017). Kasuranganan adalah taman bidadari atau taman surga nimfa (Soekmono, 2005). Telaga mata air Sumberawan berfungsi sebagai patirtan (taman pemandian pada jaman dahulu). Pada umumnya patirtan berada jauh dari keramaian. Biasanya berada di hutan lebat (contohnya: Simbatan Wetan, Belahan, Jalatunda, dan Kasurangganan) (Dharma, 2009).

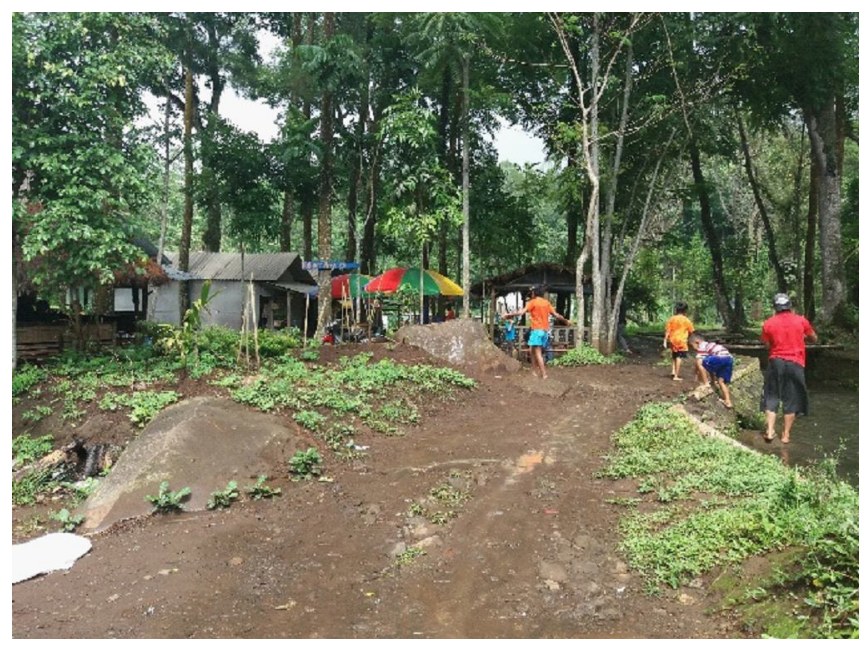

Gambar 4. Fasilitas wisata Situs Sumberawan (Sumber: Syamsun, 2017) 


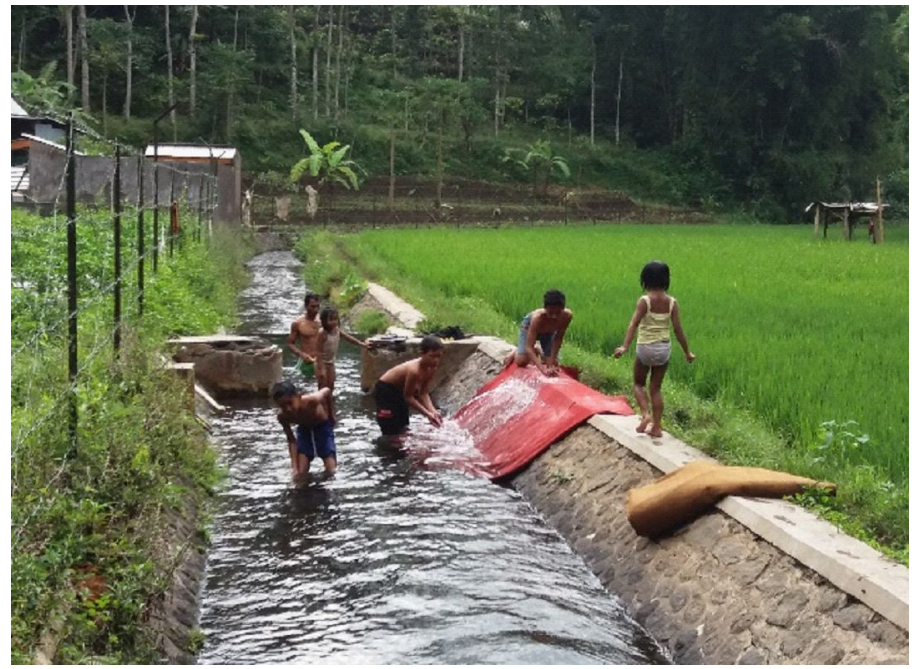

Gambar 5. Warga dusun Sumberawan menggunakan kalen air Sumberawan untuk keperluan sehari-hari (Sumber: Syamsun, 2017)

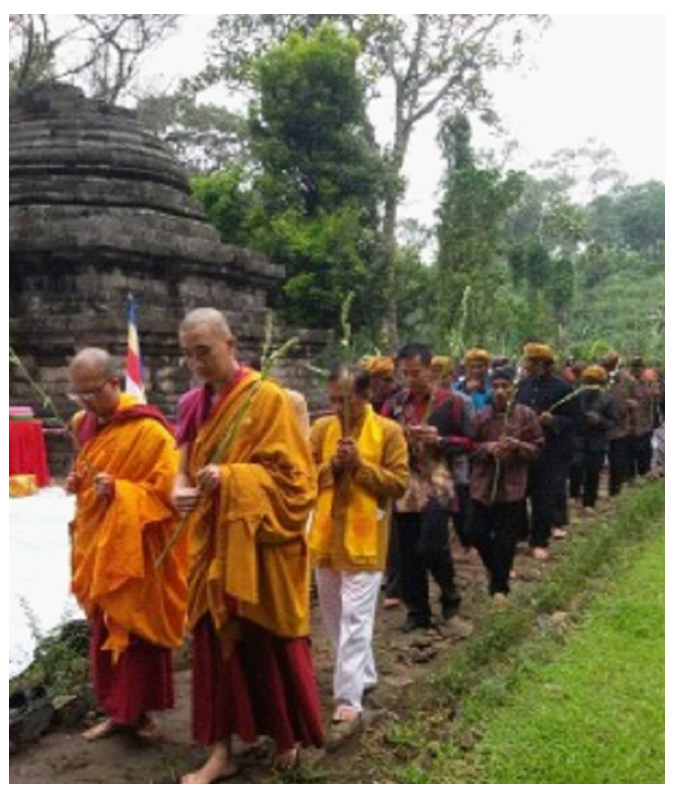

Gambar 6. Upacara pradaksina di Stupa Sumberawan (Sumber: https://kebudayaan.kemdikbud.go.id)

\section{Situs Sumberawan Sebagai Tempat non-Ritual}

Selain sebagai tempat ritual, Situs Sumberawan berfungsi sebagai tempat wisata. Mereka datang dengan tujuan untuk rekreasi, fotografi, berkemah, penelitian, berdagang. Masyarakat dusun Sumberawan menggunakan telaga mata air sebagai sumber air bersih dan sumber air untuk pertanian (Titisari, 2016). Wisata Sumberawan mulai dilirik oleh para wisatawan. Penambahan lampion warna- 
warni hingga tempay tidur gantung menambah daya tarik bagi wisatawan. Hal ini meningkatkan jumlah wisatawan (Kuncoro, 2017).

Keberadaan mata air menjadi vital bagi masyarakat sekitar Situs Sumberawan. Warga sekitar memanfaatkan kalen dari mata air yang tidak terlalu jauh dari Stupa Sumberawan untuk mandi dan mencuci setiap hari. Anak-anak mempergunakannya untuk bermain dan memancing. Masyarakat Toyomerto melakukan slametan banyu sebagai bentuk syukur atas anugerah mata air Sumberawan (Titisari, 2017). Acara ini dilaksanakan pada bulan suro. Kamituwo (kepala dukuh) memimpin arakarakan dari kantor kepala desa menuju telaga mata air. Dalam arak-arakan masyarakat membawa hasil bumi, bibit pohon dan bahan makanan. Di telaga mata air kamituwo mengambil air dan dimasukan ke dalam kendi kemudian dibawa ke kantor desa. Masyarakat berebut mencabut gunungan (jabutan) untuk mendapatkan berkah (ngalap berkah). Pada malam harinya diselenggarakan pagelaran wayangan sakral dengan lakon Jumenenge Kiyai Lurah Semar. Pagelaran ini diselingi pertunjukan Gambyong, Jaranan, Beskalan Putri, Reog, Singo dan tari Kreasi Baru Sumberawan (Indo, 2017).

\section{Situs Sumberawan Sebagai Tempat Ritual}

Masyarakat mempercayai pada jaman dahulu Situs Sumberawan merupakan tempat para leluhur bersemedi dan melakukan moksa (Titisari, 2017). Moksa dalam bahasa sankskerta adalah proses melepaskan diri dari ikatan duniawi, melepaskan diri dari putaran reinkarnasi atau punarbawa kehidupan (Wikipedia, 2018). Moksa (mukti), adalah pembebasan dari samsara dan penderitaan bersamaan, berkaitan dengan siklus kematian dan kelahiran kembali yang berulang-ulang (Samineni, n.d.). Masyarakat percaya pada jaman dahulu Resi Patmoaji dan Dewi Singowati (saudari dari Ken Dedes) melakukan moksa di Situs Sumberawan. Merekalah yang menjaga sumber air (mbaurekso) sampai saat ini (Titisari, 2017). Keyakinan ini membuat orang datang untuk beribadah dan berdoa, mandi dan meminum air dari telaga mata air Sumberawan.

Bikhu Sangga dari Sangga Agung Agung Indonesia melakukan ritual pradaksina di Stupa Sumberawan. Ritual pradaksina ini dilakukan menjelang detik-detik Waisak 2560 TB atau tahun 2016 Masehi (Direktorat Jenderal Kebudayaan, 2017). Ritual pradaksina dilakukan dengan mengelilingi Stupa Sumberawan searah jarum jam dari timur ke barat sebanyak 3 kali sebagai penghormatan kepada para Dewa (Sugata, 2016). Hal ini memiliki arti Budha-Dharma-Sangha sebagai ajaran dari sang Budha (Direktorat Jenderal Kebudayaan, 2017). Mengelilingi benda yang dianggap suci banyak dijumpai sebagai pola ritual berbagai agama dan kepercayaan (Cahyono, 2017). Kelengkapan ibadah yang dibawa saat ritual pradaksina adalah patung Budha, air suci, dupa, lilin, dan bunga sedap malam. Pada saat ritual pradaksina dilantunkan doa berbahasa pali (Kebudayaan, 2016). Ritual pradaksina ini dihadiri warga Malang Raya dan warga kawasan Gunung Bromo (Rahmawan, 2015).

Ruang ritual yang digunakan pada upacara pradaksina ini adalah Stupa Sumberawan sebagai simbol agama Budha. Telaga mata air tidak menjadi ruang ritual pradaksina ini. Khasiat air telaga mata air tidak mempunyai hubungan dengan ritual pradaksina di Situs Sumberawan (Titisari, 2016).

Masyarakat jawa penganut kejawen adalah masyarakat yang memiliki kebatinan (keadaan batin) untuk mencapai eksistensi yang tinggi sebagai manusia. Perbedaan antara segi lahir dan segi batin menjadi awal pandangan dunia Jawa (Chakim, 2011). Dalam kepercayaan kejawen segi batin merupakan sikap subjektifitas. Segi batin lebih ditekankan pada rasa dalam mencapai kesempurnaan. Kebenaran 
dan kesempurnaan akan semakin tajam apabila kekuatan rasa semakin tinggi. Inti penting dari kejawen adalah kebatinan, penggarapan secara tekun dan cermat kehidupan batin dan diri manusia (Soehada, 2008).

Pandangan dan praktikritual kejawen adalah sebagai berikut: Keyakinan kepada Gusti Alllah. Gusti Allah niku mboten wonten wujude, Gusti sing wujud lan sing ora wujud. Sing ora wujud kula percaya marang awake dhewe, artine Gusti Allah iku ana ing awake dhewe (Tuhan itu tidak berwujud, Tuhan yang berwujud dan yang tidak berwujud. Yang tidak berwujud, saya percaya kepada diri sendiri artinya Tuhan itu ada dalam hati kita). Laku atau nyepi di makam-makam yang dianggap keramat merupakan bentuk pencarian terhadap Gusti Allah. Masyarakat kejawen mempercayai ada media atau perantara dalam setiap kegiatan ritual. Perantara tersebut adalah Mbah Kajoran, walaupun beliau sudah meninggal ratusan tahun yang lalu (Chakim, 2011).

Masyarakat kejawen yang melakukan ritual di Situs Sumberawan tidak menggunakan Stupa Sumberawan sebagai ruang ritual (Titisari, 2016). Mereka menggunakan telaga mata air dan kalen (sungai yang mengalirkan air dari telaga mata air) sebagai ruang ritual. Masyarakat kejawen melakukan ritual tersebut karena keyakinan terhadap khasiat air telaga mata air tersebut dari cerita leluhur mereka (Titisari, 2016). Masyarakat kejawen melakukan ritual mandi suci di telaga mata air dan aliran sungainya di Situs Sumberawan. Ritual mandi suci ini di lasanakan pada malam Jumat legi. Bagi masyarakat kejawen Stupa Sumberawan adalah penanda dimana penjaga mata air berdiam (Titisari, 2016).

\section{Makna Ruang Situs Sumberawan}

Penganut agama Budha menggunakan Stupa Sumberawan sebagai ruang ritual. Penganut kejawen menggunakan telaga mata air dan sungainya sebagai ruang ritual. Masyarakat Dusun Sumberawan setiap hari menggunakan sungai aliran telaga mata air sebagai tempat mandi, mencuci, dan mencari ikan. Anak-anak di Dusun Sumberawan menjadikan aliran sungai sebagai tempat bermain dan memancing. Wisatawan non-ritual menjadikan Stupa Sumberawan, telaga mata air, sungai, dan seluruh area Situs Sumberawan sebagai tempat rekreasi. Melihat dari penggunaan Situs Sumberawan terlihat area Situs Sumberawan memiliki makna masing-masing yang berbeda-beda.

\section{Pelestarian Situs Sumberawan}

Undang-undang Republik Indonesia Nomor 11 Tahun 2010 tentang Cagar Budaya pasal 1 menyatakan bahwa Cagar Budaya adalah warisan budaya bersifat kebendaan berupa Benda Cagar Budaya, Bangunan Cagar Budaya, Struktur Cagar Budaya, Situs Cagar Budaya, dan Kawasan Cagar Budaya di darat dan/atau di air yang perlu dilestarikan keberadaannya karena memiliki nilai penting bagi sejarah, ilmu pengetahuan, pendidikan, agama, dan/atau kebudayaan melalui proses penetapan. Perlindungan Cagar Budaya adalah upaya mencegah dan menanggulangi dari kerusakan, kehancuran, atau kemusnahan dengan cara penyelamatan, pengamanan, zonasi, pemeliharaan, dan pemugaran. Di dalam pasal 3 undang-undang tersebut menjelaskan tujuan dari pelestarian Cagar Budaya adalah: (a) melestarikan warisan budaya bangsa dan warisan umat manusia; (b) meningkatkan harkat dan martabat bangsa melalui Cagar Budaya; (c) memperkuat kepribadian bangsa; (d) meningkatkan kesejahteraan rakyat; dan (e) mempromosikan warisan budaya bangsa kepada masyarakat internasional. Di dalam undang-undang terlihat pelestarian Cagar Budaya hanya melihat aspek fisik. Otentisitas merupakan 
aspek dalam konservasi pusaka budaya yang disusun Unesco atau ICOMOS (Titisari, 2016). Namun di Asia termasuk di Indonesia otentisitas takbenda merupakan hal yang lebih diutamakan dalam konservasi pusaka budaya (Kwanda, 2013). Ekpresi kehidupan sosial, spiritual, dan aspek simbolis merupakan representasi konsep kosmologi masyarakat timur, sebagai mikrokosmos dari alam semesta (Kwanda, 2013). Dengan demikian adalah arif apabila melihat pelestarian bukan hanya aspek fisik saja, namun melihat aspek budaya (sisi ideologis) yang terkandung di dalamnya.

Di dalam Piagam Pelestarian Pusaka Indonesia dijelaskan bahwa Pusaka Indonesia adalah pusaka alam, pusaka budaya, dan pusaka saujana. Pusaka alam adalah bentukan alam yang istimewa. Pusaka budaya adalah hasil cipta, rasa, karsa, dan karya yang istimewa dari lebih 500 suku bangsa di Tanah Air Indonesia, secara sendiri-sendiri, sebagai kesatuan bangsa Indonesia, dan dalam interaksinya dengan budaya lain sepanjang sejarah keberadaannya. Pusaka budaya mencakup pusaka berwujud dan pusaka tidak berwujud. Pusaka saujana adalah gabungan pusaka alam dan pusaka budaya dalam kesatuan ruang dan waktu (JPPI \& ICOMOS, 2003).

Tabel 1. Iktisar penilaian terhadap Candi Sumberawan

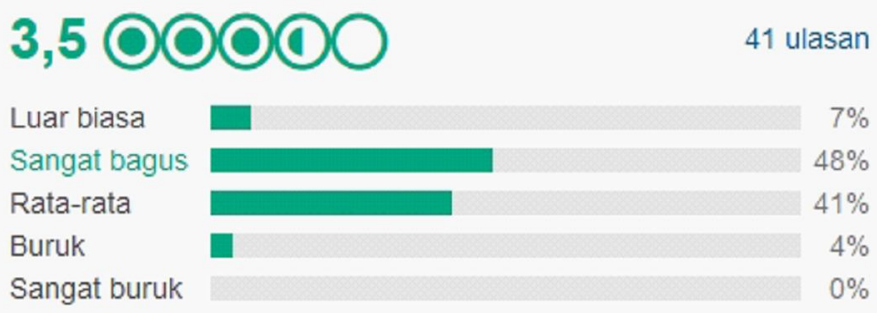

Sumber: https://www.tripadvisor.co.id

Diakses pada 21 Desember 2017

Pelestarian secara fisik Stupa Sumberawan pada saat ini dapat dilakukan dengan langkah pengamanan, zonasi, dan pemeliharaan. Mengenai pelestarian ini tampaknya masyarakat sudah mempunyai kesadaran dengan melihat pendapat mereka di dalam situs penyedia layanan wisata._Melihat ulasan yang dimuat oleh https://www.tripadvisor.co.id, penilaian masyarakat umum terhadap Candi Sumberawan diperlihatkan sebagai berikut:

Beberapa pendapat masyarakat mengenai Candi Sumberawan adalah: (1) Situs purba yang wajib dilestarikan; (2) Salah satu bukti sejarah yang tersembunyi: (3) Candi sejarah yang perlu lebih diperhatikan; (4) Candi sejarah yang terlupakan; (5) Pemandangan yang luar biasa; (6) Akses jauh; (7) Lokasi yang mengagumkan, sejuk, segar, alami, air jernih; (8) Candi yang belum populer; (9) Tempat yang cocok untuk ketenangan (Tripadvisor, 2017).

Situs Sumberawan sebagai tempat berjualan bagi masyarakat sekitar tentu baik dan buruknya sarana dan prasarana berdagang menciptakan citra tersendiri bagi pariwisata Situs Sumberawan. Perbaikan dalam perancangan dan perencanaan kios-kios di area Situs Sumberawan harus dilakukan untuk menciptakan suasana Situs Sumberawan sebagai tempat wisata dengan pengeloaan yang baik. Kios-kios makanan di tepi kalen dapat dirancang dan direncanakan kembali menggunakan bangunan permanen yang lebih baik dan mendukung Situs Sumberawan sebagai wisata sejarah dan budaya. 
Nilai-nilai luhur berketuhanan mendasari pola pikir manusia dalam membentuk kebudayaan. Makna kultural berkaitan dengan budaya (Titisari, 2016). Wujud kebudayaan intangible Situs Sumberawan dapat dimaknai sebagai kepercayaan masyarakat terhadap tradisi, mitos, khasiat, ritual, festival budaya di telaga mata air. Sehingga keberadaan Situs Sumberawan tidak bisa dipisahkan dengan keberadaan mata air. Simbol-simbol berbentuk ritual, bidadari, roh leluhur, mitos dan larangan adalah upaya dalam menjaga sumber mata air untuk keselamatan, ketentraman, dan kelestarian kosmos (Ariani, 2003).

\section{Kesimpulan}

Terdapat perbedaan dalam memaknai ruang Situs Sumberawan dari berbagai pengguna. Baik masyarakat sekitar, pedagang, wisatawan non-ritual, maupun wisatawan dengan tujuan ritual. Perbedaan makna ruang ini dapat menjadi landasan dalam pelestarian Situs Sumberawan. Pelestarian Situs Sumberawan harus dilakukan meliputi:

- Pelestarian Stupa Sumberawan dan artefak-artefak peninggalannya.

- Pelestarian lingkungan alam di sekitar Stupa Sumberawan.

- Pelestarian sumber mata air dengan melestarikan budaya dengan simbol-simbol yang berbentuk ritual, kepercayaan terhadap skeberadaan punden, bidadari, roh leluhur, mempercayai mitos dan larangan di telaga mata air.

\section{Referensi}

Ariani, C. (2003). Upacara Bersih Dusun Gua Cerme, Desa Selopamioro Kabupaten Bantul sebagai Wujud Solidaritas Sosial.

Cahyono, D. (2017). Pratipa (Prasawya Tirtha Ppawitra)/ : Tirthayatra Mengitari Ardi Suci Penanggungan. Retrieved from https:/ / patembayancitraleka. wordpress.com/2017/03/15/prasawya-tirtha-pawitra/

Chakim, S. (2011). Potret islam sinkretisme: praktik ritual kejawen? Jurnal KOMUNIKA, 3(1), 1-9. https://doi.org/ 1978-1261

Dharma, P. H. I. P. (2009). Majapahit Dalam Sejarah (2). Retrieved from http://phdi.or.id/artikel/majapahit-dalamsejarah-2

Direktorat Jenderal Kebudayaan, K. P. dan K. (2017). Trisuci Waisak di Candi Sumberawan. Retrieved December 30, 2017, from https://kebudayaan.kemdikbud.go.id/bpcbjatim/2016/05/24/trisuci-waisak-di-candisumberawan/

Djafar, H. (2012). Masa akhir Majapahit/ : Girindrawarddhana \& masalahnya.

Ganesha, P. B. A. (2017). Kisah Pemutaran Mandara Giri: Pencarian Tirta Amerta. Retrieved from http:// www.pasramanganesha.sch.id/2012/10/kisah-pemutaran-mandara-giri-pencarian.html

Indo, B. (2017). Ritual Patirtaan Candi Sumberawan Kabupaten Malang Ajak Masyarakat Jaga Sumber Mata Air. Retrieved from http://suryamalang.tribunnews.com/2017/11/05/ritual-patirtaan-candi-sumberawankabupaten-malang-ajak-masyarakat-jaga-sumber-mata-air

JPPI \& ICOMOS. (2003). Piagam Pelestarian Pusaka Indonesia - Indonesian Charter for Heritage Conservation, 1-4. 


\section{LOCAL WISDOM, Vol. 10 No. 1 Januari 2018}

Local Wisdom Scientific Online Journal

Kebudayaan, D. J. (2016). Trisuci Waisak di Candi Sumberawan. Retrieved from https://kebudayaan.kemdikbud.go.id/bpcbjatim/2016/05/24/trisuci-waisak-di-candi-sumberawan/

Kuncoro, A. (2017). Wana Wisata Candi Sumberawan Kian Bersolek. Retrieved from http://www.radarmalang.id/ wana-wisata-candi-sumberawan-kian-bersolek/

Kwanda, T. (2013). Otensitas Takbenda Dalam Tradisi Konservasi Di Kompleks Ki Buyut Trusmi, Cirebon, 1-8.

Marsudi. (2015). Bangkitnya Tradisi Neo-Megalithik di Gunung Arjuno.

Nuryadi. (2017). Sejarah Stupa Sumberawan.

Rahmawan, M. D. E. (2015). Candi Sumberawan Dibanjiri Umat. Retrieved from http://www.malangtimes.com/ baca/247/20150602/160201/candi-sumberawan-dibanjiri-umat/

Samineni, L. (n.d.). Moksa: The Goal Of Life.

Setyani, T. I. (2011). Meniti sinkretisme teks tantu pangg ì laran, 1(2), 132-144.

Soehada, M. (2008). Orang Jawa Memaknai Agama. Yogyakarta: Kreasi Wacana.

Soekmono, R. (2005). Candi/ : fungsi dan pengertiannya. [Jakarta?]/ : Jendela Pustaka.

Sugata, F. (2016). Keterkaitan Aktivitas Pradaksina Pada Ragam Tipologi, 1(2), 210-234.

Sunyoto, A. (2000). Buku Petunjuk Wisata Sejarah Kabupaten Malang. Malang: Lingkar Studi Kebudayaan.

Suwardono. (n.d.). Stupa Sumberawan.

Titisari. (2016). Makna Kultural Situs Sumberawan/ : Masa Lalu, (March 2017).

Titisari. (2017). Intangible Cultural Heritage Candi Sumberawan Dalam Perspekstif Kosmologi. Seminar Nasional 2017 "Heritage: Tangible \& Intangible Aspects". Cirebon 3-4 Mei., (1), 17-22.

Titisari, E. Y., Antariksa, Dwi, L. W., \& Surjono. (2017). Intangible Cultural Heritage Candi Sumberawan Dalam Perspekstif Kosmologi. Seminar Nasional 2017 "Heritage: Tangible \& Intangible Aspects". Cirebon 3-4 Mei., (May).

Titisari, E. Y., Antariksa, Dwi, L. W., \& Surjono. (2017). Sumber Air Dalam Ruang Budaya Masyarakat Desa Toyomerto Singosari, Malang Menggali Kearifan Lokal Mengenai Water Resources Sustainability. Seminar Nasional Arsitektur Dan Tata Ruang (SAMARTA), 1-9.

Tripadvisor. (2017). Candi Sumberawan. Retrieved from https:/ /www.tripadvisor.co.id/Attraction_Review-g297710d3356829-Reviews-Sumberawan_Temple-Malang_East_Java_Java.html

Wikipedia. (2018). Moksa. Retrieved from https://id.wikipedia.org/wiki/Moksa

Wurianto, A. B. (2009). Aspek budaya pada upaya konservasi air dalam situs kepurbakalaan dan mitologi masyarakat Malang, IV. 